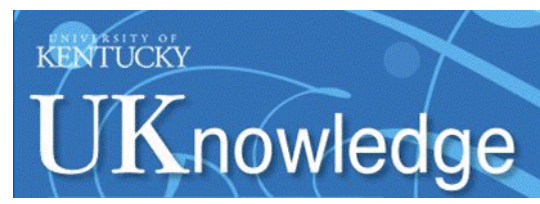

University of Kentucky

UKnowledge

\title{
Century-Long Increasing Trend and Variability of Dissolved Organic Carbon Export from the Mississippi River Basin Driven by Natural and Anthropogenic Forcing
}

Wei Ren

University of Kentucky, wei.ren@uky.edu

Hanqin Tian

Auburn University

Wei-Jun Cai

University of Delaware

Steven E. Lohrenz

University of Massachusetts - Dartmouth

Charles S. Hopkinson

University of Georgia

Follow this and additional works at: https://uknowledge.uky.edu/pss_facpub

2 next page for additional authors

Part of the Environmental Sciences Commons

Right click to open a feedback form in a new tab to let us know how this document benefits you.

\section{Repository Citation}

Ren, Wei; Tian, Hanqin; Cai, Wei-Jun; Lohrenz, Steven E.; Hopkinson, Charles S.; Huang, Wei-Jen; Yang, Jia; Tao, Bo; Pan, Shufen; and He, Ruoying, "Century-Long Increasing Trend and Variability of Dissolved Organic Carbon Export from the Mississippi River Basin Driven by Natural and Anthropogenic Forcing" (2016). Plant and Soil Sciences Faculty Publications. 82.

https://uknowledge.uky.edu/pss_facpub/82

This Article is brought to you for free and open access by the Plant and Soil Sciences at UKnowledge. It has been accepted for inclusion in Plant and Soil Sciences Faculty Publications by an authorized administrator of UKnowledge. For more information, please contact UKnowledge@lsv.uky.edu. 


\section{Century-Long Increasing Trend and Variability of Dissolved Organic Carbon Export from the Mississippi River Basin Driven by Natural and Anthropogenic Forcing}

Digital Object Identifier (DOI)

https://doi.org/10.1002/2016GB005395

Notes/Citation Information

Published in Global Biogeochemical Cycles, v. 30, issue 9, p. 1288-1299.

(C2016. American Geophysical Union. All Rights Reserved.

The copyright holders have granted the permission for posting the article here.

\section{Authors}

Wei Ren, Hanqin Tian, Wei-Jun Cai, Steven E. Lohrenz, Charles S. Hopkinson, Wei-Jen Huang, Jia Yang, Bo Tao, Shufen Pan, and Ruoying He 


\section{Global Biogeochemical Cycles}

\section{RESEARCH ARTICLE}

10.1002/2016GB005395

\section{Key Points:}

- A century-long increase in dissolved organic carbon export occurred from the Mississippi River basin

- Land use and land management practices dominated DOC export increase

- Climate change/extremes controlled interannual and decadal variations in DOC export

Supporting Information:

- Supporting Information S1

Correspondence to:

W. Ren, and H. Tian,

wei.ren@uky.edu;

tianhan@auburn.edu

\section{Citation:}

Ren, W., H. Tian, W.-J. Cai, S. E. Lohrenz, C. S. Hopkinson, W.-J. Huang, J. Yang, B. Tao, S. Pan, and R. He (2016), Century long increasing trend and variability of dissolved organic carbon export from the Mississippi River basin driven by natural and anthropogenic forcing, Global Biogeochem. Cycles, 30,

1288-1299, doi:10.1002/ 2016GB005395.

Received 17 FEB 2016 Accepted 11 AUG 2016 Accepted article online 15 AUG 2016 Published online 5 SEP 2016

\section{Century-long increasing trend and variability of dissolved organic carbon export from the Mississippi River basin driven by natural and anthropogenic forcing}

\author{
Wei Ren ${ }^{1}$, Hanqin Tian ${ }^{2}$, Wei-Jun Cai ${ }^{3}$, Steven E. Lohrenz ${ }^{4}$, Charles S. Hopkinson ${ }^{5}$, Wei-Jen Huang ${ }^{6}$, \\ Jia Yang ${ }^{2}$, Bo Tao ${ }^{1}$, Shufen Pan' ${ }^{2}$, and Ruoying $\mathrm{He}^{7}$ \\ 1Department of Plant and Soil Sciences, College of Agriculture, Food and Environment, University of Kentucky, Lexington, \\ Kentucky, USA, ${ }^{2}$ International Center for Climate and Global Change Research, Auburn University, Auburn, Alabama, USA, \\ ${ }^{3}$ School of Marine Science and Policy, University of Delaware, Newark, Delaware, USA, ${ }^{4}$ School for Marine Science and \\ Technology, University of Massachusetts Dartmouth, New Bedford, Massachusetts, USA, ${ }^{5}$ Department of Marine Sciences, \\ University of Georgia, Athens, Georgia, USA, ${ }^{6}$ Department of Oceanography, National Sun Yat-sen University, Kaohsiung, \\ Taiwan, ${ }^{7}$ Department of Marine, Earth and Atmospheric Sciences, North Carolina State University, Raleigh, North Carolina, USA
}

Abstract There has been considerable debate as to how natural forcing and anthropogenic activities alter the timing and magnitude of the delivery of dissolved organic carbon (DOC) to the coastal ocean, which has ramifications for the ocean carbon budget, land-ocean interactions, and coastal life. Here we present an analysis of DOC export from the Mississippi River to the Gulf of Mexico during 1901-2010 as influenced by changes in climate, land use and management practices, atmospheric $\mathrm{CO}_{2}$, and nitrogen deposition, through the integration of observational data with a coupled hydrologic/biogeochemical land model. Model simulations show that DOC export in the 2000 s increased more than $40 \%$ since the 1900 s. For the recent three decades (1981-2010), however, our simulated DOC export did not show a significant increasing trend, which is consistent with observations by U.S. Geological Survey. Our factorial analyses suggest that land use and land cover change, including land management practices (LMPs: i.e., fertilization, irrigation, tillage, etc.), were the dominant contributors to the century-scale trend of rising total riverine DOC export, followed by changes in atmospheric $\mathrm{CO}_{2}$, nitrogen deposition, and climate. Decadal and interannual variations of DOC export were largely attributed to year-to-year climatic variability and extreme flooding events, which have been exacerbated by human activity. LMPs show incremental contributions to DOC increase since the 1960s, indicating the importance of sustainable agricultural practices in coping with future environmental changes such as extreme flooding events. Compared to the observational-based estimate, the modeled DOC export was $20 \%$ higher, while DOC concentrations were slightly lower. Further refinements in model structure and input data sets should enable reductions in uncertainties in our prediction of century-long trends in DOC.

\section{Introduction}

Dissolved organic carbon (DOC) flux from terrestrial landscapes to rivers and further to the ocean is a fundamental component of the global carbon cycle [Butman et al., 2016; Dai et al., 2012; Meybeck, 1993; Schlesinger and Melack, 1981; Smith and Hollibaugh, 1993]. DOC produced in terrestrial, riverine, and ocean ecosystems is the major source of organic carbon fueling microbial food webs, and DOC in marine and freshwater systems represents one of the greatest cycled reservoirs of organic matter on Earth [Butman and Raymond, 2011; Cole et al., 2007]. Small changes in the carbon balance of the terrestrial biosphere could result in large changes in riverine DOC flux [Aitkenhead and McDowell, 2000] and hence could alter DOC concentrations in freshwater and marine systems [Hedges, 1992]. It is imperative to investigate the variations in the timing and magnitude of DOC export and explore the underlying mechanisms to increase our ability to predict biogeochemical consequences of natural and anthropogenic changes.

Changes in the terrestrial environment, both natural (e.g., climate change, atmospheric $\mathrm{CO}_{2}$, and fire) and anthropogenic (e.g., deforestation, cropland expansion, agricultural land management, and urbanization), have greatly altered carbon production, stocks, decomposition, movement, and export from land to river and ocean systems [Bengtson and Bengtsson, 2007; Canuel et al., 2012; Christ and David, 1996; Liu and Greaver, 2010; Zhang et al., 2013]. For example, recent synthesis studies revealed a large increase in carbon 
transport from land to ocean caused by human actives since preindustrial times (e.g., land use changes, soil erosion, liming, and fertilizer and pesticide application), which had been ignored in estimating the global carbon budget [Regnier et al., 2013]. Climate change also plays an important role in altering DOC production and turnover in soil and DOC sources and fates in coastal ecosystems [Bengtson and Bengtsson, 2007; Canuel et al., 2012]. Extreme climate events can lead to increases in riverine DOC export [Dhillon and Inamdar, 2013; Tian et al., 2015]. Yet it remains unclear how natural and anthropogenic factors individually and interactively contribute to carbon transport, which can considerably hinder our efforts to assess the global carbon budget as well as to effectively manage coastal ecosystems and water quality.

As the third largest drainage basin area in the world, the Mississippi River basin contains one of the most productive agricultural regions in the world, and has been profoundly influenced by rapid changes in land use and human activity over the past century [Chen et al., 2006; Foley et al., 2004; Mackenzie et al., 2000; Zhang et al., 2012]. These changes have greatly altered the magnitude, annual and decadal variations, and centurial trend of DOC fluxes from land to the Gulf of Mexico. In this study, we first analyzed the observed DOC concentration from the United States Geological Survey (USGS) gauging station (St. Francisville, LA) for the last three decades. We then used a process-based, coupled hydrological/biogeochemical model [Liu et al., 2013; Tian et al., 2010], in combination with spatially explicit historical environmental information (see section 2), to investigate the spatial and temporal patterns of riverine DOC fluxes from the Mississippi River basin to the Gulf of Mexico from 1901 to 2010. We then conducted factorial simulation experiments to examine the effects of major natural and anthropogenic factors on DOC export over the study period. This study illuminates how climate and land use changes likely alter DOC export from land to the ocean on a centurial time scale.

\section{Methods and Data}

\subsection{Data Sources}

The data sets used for synthesis, analysis, and model evaluation were compiled from long-term observational data of water discharge and DOC concentration provided by the USGS Water Quality Samples for the Nation (http://www.usgs.gov/water/) at Mississippi River subbasin and whole basin levels. Two DOC data sets derived from unfiltered (1981-1995) and filtered (1996-2010) water samples were compiled into continuous time series of DOC flux for further analysis and model evaluation (see Text S2 in the supporting information). The model was calibrated against a database collected from published field experiments and metadata analyses (e.g., the amount of DOC leached per unit area in diverse ecosystems such as cropland, grassland, and forest). Details regarding calibration procedures can be found in our previous publications [Tian et al., 2015; Liu et al., 2013].

To examine the controls and causes of temporal and spatial variability in DOC flux, we developed historical gridded data sets with a spatial resolution of $5 \times 5$ arc min (approximately $9.2 \times 9.2 \mathrm{~km}$ at the equator) that characterize changes in climate conditions (temperature, precipitation, radiation, humidity, etc.), atmospheric $\mathrm{CO}_{2}$, nitrogen deposition, and anthropogenic perturbations including land cover patterns and land management practices in terrestrial ecosystems of the Mississippi River basin for the period 1901-2010. These data sets were developed from multiple sources, and detailed information about data development was reported in our previous work [Liu et al., 2013; Tian et al., 2010].

\subsection{The Coupled Hydrologic/Biogeochemical Modeling Approach}

The Dynamic Land Ecosystem Model (DLEM), a coupled hydrological/biogeochemical land model provides daily, spatially explicit estimates of carbon, nitrogen, and water fluxes and pool sizes in terrestrial ecosystems and continental margin. It consists of five core components: biophysical characteristics, hydrological and biogeochemical cycles, plant physiological processes, vegetation dynamics, and land use and management. The DLEM 2.0 uses a cohort structure and is characterized by multiple soil layer processes, coupled carbon, water and nitrogen cycles, enhanced land surface processes, and dynamic linkages between terrestrial and riverine ecosystems [Liu et al., 2013; Tao et al., 2014; Tian et al., 2015; Yang et al., 2015; Ren et al., 2015]. In this study, the DLEM simulates the production, consumption, and transport of dissolved organic carbon in soils and surface waters. It does this by incorporating multiple effects derived from the spatial heterogeneity in climate change (e.g., precipitation and temperature), atmospheric $\mathrm{CO}_{2}$, nitrogen deposition, and land cover change and land management practices (e.g., irrigation, nitrogen fertilizer, and harvesting). An illustration of the key processes 


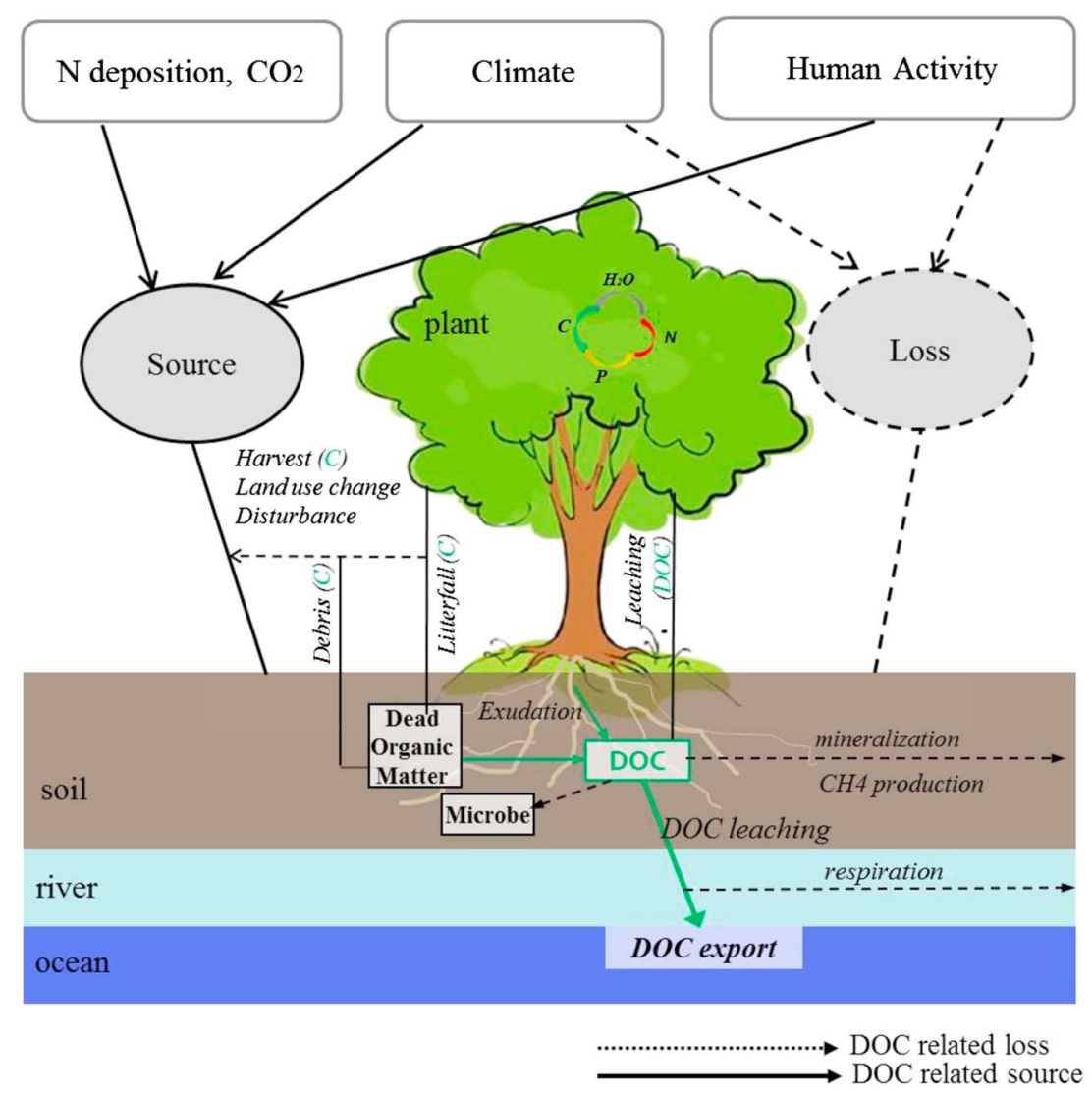

Figure 1. Key compartments, processes, and driving forces associated with production, consumption, storage, and transport of dissolved organic carbon (DOC) in the Dynamic Land Ecosystem Model (DLEM).

influencing DOC production, loss and transports in the DLEM model, and the mechanistic control by changes in natural and anthropogenic factors is given in Figure 1. Details regarding model simulations and the key processes controlling DOC production [Liu et al., 2005; Parton et al., 1993; Petersen et al., 2005], transformation, loss [Chantigny, 2003], and transport [Coe, 2000] can be found in the supporting information for this article (Text SI) and a recent publication [Tian et al., 2015].

\subsection{Model Evaluation}

In our previous work, key biogeochemical parameters were calibrated against field observations at multiple sites throughout North America, including the Mississippi River basin [Chen et al., 2012; Ren et al., 2015; Tian et al., 2010; Tian et al., 2012; Xu et al., 2012]. In particular, hydrologically related parameters and key variables (runoff, evapotranspiration, river discharge, etc.) were calibrated and evaluated in our recent publications [Liu et al., 2013; Pan et al., 2015; Tao et al., 2014]. Our recent study [Tian et al., 2015] evaluated DOC fluxes against USGS water quality data at the subbasin levels (including sites along the Missouri River at Omaha (site No. 6610000) and Hermann (site No. 6934500), the Mississippi River at Grafton (site No. 5587450), and the Arkansas River near Little Rock (site No. 7263450)) during 2001-2010.

In this study, we collected more data and further evaluated the simulated DOC fluxes at the whole basin level (Mississippi River at St. Francisville). We consider the effect of sampling period on DOC flux estimation and apply Weighted Regressions on Time, Discharge, and Season (WRTDS) [Hirsch, 2014] with an R package (Exploration and Graphics for RivEr Trends) to estimate monthly and annual DOC fluxes (see details in Text S2). We used the most reliable data (since 1996) to evaluate model-simulated DOC concentration values (Figure 2) and also examined the temporal patterns of DOC flux and river discharge since 1981 (Figure S2). Finally, we compared model results with estimates of mean annual DOC export reported in other studies, including field observations [Trefry et al., 1994; Benner and Opsahl, 2001; Bianchi et al., 2004; Shen et al., 2012; 

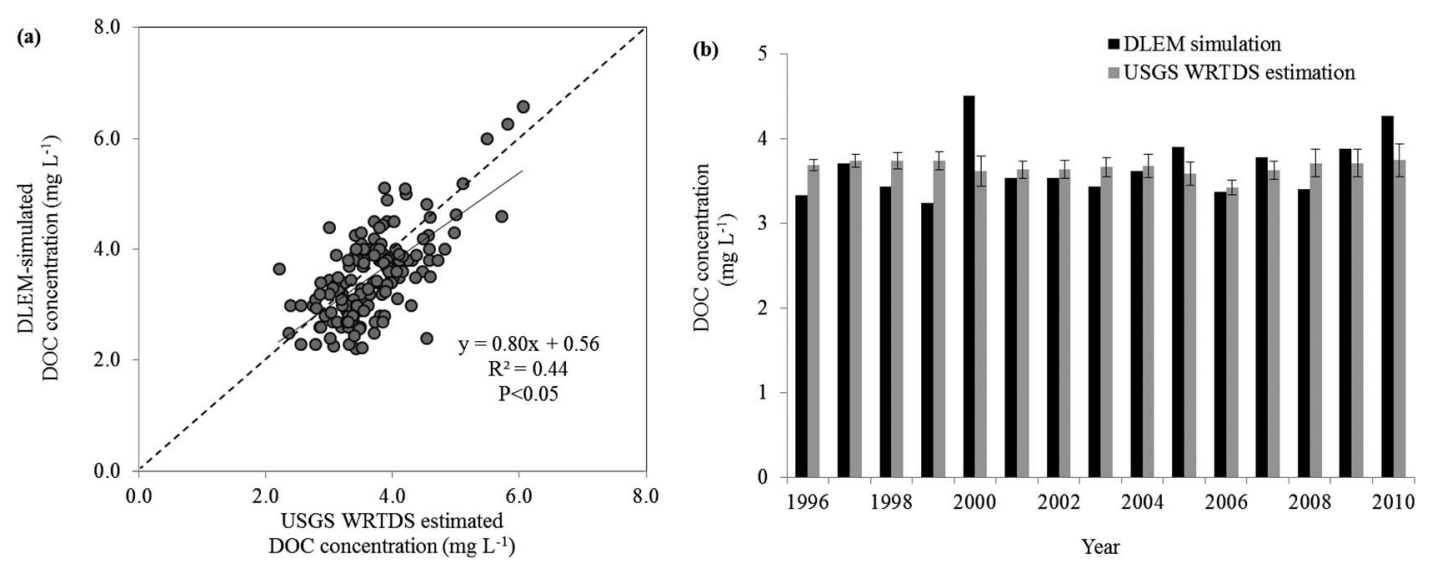

Figure 2. Comparisons of (a) monthly dissolved organic carbon (DOC) concentrations ( $\mathrm{mg} \mathrm{L}^{-1}$ ), (b) annual mean DOC concentrations ( $\mathrm{mg} \mathrm{L}^{-1}$ ) between DLEM simulations and station observations from the Mississippi River at St. Francisville (USGS site No. 07373420) during 1996-2010. Note: USGS values were estimated by the WRTDS approach and the error bars represent standard deviations around the annual means of USGS WRTDS estimates.

Lohrenz et al., 2014], gauging stations [Smith et al., 2005], empirical estimates [Ludwig et al., 1996], and other process-based modeling approaches [Harrison et al., 2005] (see Table S1 in the supporting information).

In general, our simulated mean DOC concentrations are comparable to observations. The DLEM-simulated

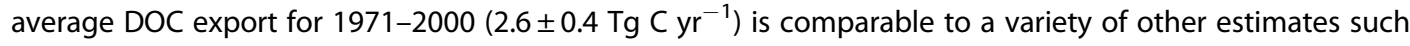
as Load Estimator (LOADEST) data (2.5 $\left.\mathrm{Tg} \mathrm{C} \mathrm{yr}^{-1}\right)$ [Stets and Striegl, 2012], model-based estimates from the Global Nutrient Export from WaterSheds (NEWS) model (2.6 $\mathrm{Tg} \mathrm{C} \mathrm{yr}^{-1}$ ) [Harrison et al., 2005], and a synthesis of field observations (2.6 $\mathrm{Tg} \mathrm{C} \mathrm{yr}^{-1}$ ) [Lohrenz et al., 2014] (Table S1).

We found that DLEM-simulated DOC concentrations were comparable to observations (Figure 2). The model also captured most temporal patterns of DOC flux and of river discharge in recent decades (Figure S2). However, our simulated DOC export was higher than observations (over 20\% for a 30 year average) (Figure S2b), while simulated DOC concentrations were lower than observed (root-mean-square deviation or RMSD between simulated and observed DOC concentrations was $0.5 \mathrm{mg} \mathrm{L}^{-1}$ for seasonal and $0.4 \mathrm{mg} \mathrm{L}^{-1}$ for annual (Figure 2). This was mainly a consequence of model estimates of river discharge being higher than observations (about $16 \%$ on 30 year average) (Figure S2a). One potential reason that our modeled estimates of river discharge were greater than observations is because the drainage basin in our simulation is about $10 \%$ larger than that defined by USGS. We also found a notable discrepancy between modeled and observed DOC fluxes in some years. For example, DLEM-simulated DOC concentration did not reflect high values around 1981 as observed by USGS but showed much higher value in 2000 than that observed. Therefore, in addition to uncertainty caused by input data, some missing or misrepresented mechanisms in DLEM model may introduce biases and variance in model results. For example, dam effects can sustainably influence river discharge and associated DOC concentration and export. Additional explanations for the differences in DOC fluxes between DLEM and other studies include differences in study periods, different methods used in various empirical studies, and different model approaches (statistical, biogeochemical and physical, and process-based ecosystem models; Table S1).

\subsection{Numerical Simulation Experiments}

The model was initiated with an equilibrium run, which used mean climate data sets to develop the simulation baselines for carbon, nitrogen, and water pools. Then a 90 year spin-up simulation (three spin-ups each of a 30 year period) was conducted using the detrended climate data to eliminate noise caused by the simulation shift from the equilibrium to the transient mode. Subsequently, the model was implemented using the time series of input data sets in the transient mode.

We designed 10 numerical experiments to investigate the causes of spatial and temporal patterns of DOC behavior in the context of multiple global changes (Table 1). To examine model fluctuation resulting from internal system dynamics, we first performed DLEM simulation (1: Reference) driven by all factors remained at 1900 levels through 1901-2010, including climate, land cover/land use change (LCLUC), land conversion 
Table 1. Simulation Design ${ }^{\mathrm{a}}$

\begin{tabular}{|c|c|c|c|c|c|c|}
\hline \multirow[b]{2}{*}{ Numerical Experiments } & \multicolumn{2}{|c|}{ Climate } & \multirow[b]{2}{*}{$\mathrm{CO}_{2}$} & \multirow[b]{2}{*}{ NDEP } & \multicolumn{2}{|c|}{ LCLUC } \\
\hline & Temperature & Precipitation & & & Land Conversion & Management Practices \\
\hline 1: Reference & 1900 & 1900 & 1900 & 1900 & 1900 & 1900 \\
\hline 2: All & 1901-2010 & 1901-2010 & 1901-2010 & 1901-2010 & 1901-2010 & 1901-2010 \\
\hline 3: Climate & $1901-2010$ & $1901-2010$ & 1900 & 1900 & 1900 & 1900 \\
\hline 4: LCLUC & 1900 & 1900 & 1900 & 1900 & 1901-2010 & 1901-2010 \\
\hline 5: $\mathrm{CO}_{2}$ & 1900 & 1900 & 1901-2010 & 1900 & 1900 & 1900 \\
\hline 6: Ndep & 1900 & 1900 & 1900 & $1901-2010$ & 1900 & 1900 \\
\hline 7: PRECIP & 1900 & 1901-2010 & 1900 & 1900 & 1900 & 1900 \\
\hline 8: $T$ & $1901-2010$ & 1900 & 1900 & 1900 & 1900 & 1900 \\
\hline 9: LC & 1900 & 1900 & 1900 & 1900 & $1901-2010$ & 1900 \\
\hline 10: LMPs & 1900 & 1900 & 1900 & 1900 & 1900 & 1901-2010 \\
\hline
\end{tabular}

${ }^{a}$ Simulation experiments include the following: Reference: all environmental factors remain unchanged from 1900 levels; All: climate, carbon dioxide ( $\left.\mathrm{CO}_{2}\right)$, nitrogen deposition (Ndep), and land cover and land use (LCLUC) change during 1901-2010; Climate: only climate changes during 1901-2010 while other factors are kept constant at 1900 levels; LC and LMPs: only land cover and land management practices (fertilizer, irrigation, etc.) change, respectively, while other factors are constant at 1900 levels; Two additional simulations are designed to examine the relative role of temperature ( $T$ ) and precipitation (PRECIP).

(LC), and land management practices (LMPs), and atmospheric chemical components (atmospheric $\mathrm{CO}_{2}$ concentration and nitrogen deposition (Ndep)). Then we conducted a combined simulation (2: All) with DLEM driven by all factors varied during 1901-2010 in order to simulate the effects of temporal and spatial dynamics of all five environmental factors on DOC fluxes from the Mississippi River basin.

To attribute the relative contributions of these factors to annual variations of $C$ export, we then designed a series of factor-specific simulation experiments, which included: 3: Climate, 4: LCLUC, 5: CO 2, and 6: Ndep. For example, to determine the effects of climate variability alone, we ran the model using the gridded historical daily data for air temperature (including maximum, minimum, and average air temperatures), relative humidity, solar radiation, and precipitation, but kept all other factors at 1900 levels.

To determine the relative role of precipitation (PRECIP) and temperature $(T)$ in DOC export variations, we conducted additional simulations to examine which climate-related variable was the dominant factor controlling the variability of DOC export: 7: PRECIP and 8: $T$.

Finally, we conducted simulations to distinguish the effects of land conversion (LC) and land management practices (LMPs) from the combined effects of LCLUC: 9: LC and 10: LMPs.

To calculate the relative contributions of these factors, we used simulation attribution analysis. We defined the overall change caused by multiple environmental factors $\left(\triangle \mathrm{DOC}_{\mathrm{all}}\right)$ as the difference between the All simulation and the Reference baseline simulation; and the change due to each factor $\left(\triangle \mathrm{DO} C_{\mathrm{factor}}\right)$ as the difference between the factor-specific experiment and the baseline. The relative contribution (percentage) of each factor to the overall change in DOC flux can then be estimated as $\triangle D O C_{\text {factori }} / \triangle D O C_{\text {all }}$ and the interactive effect calculated as $\left(\triangle D O C_{\text {all }}-\Sigma \Delta D O C_{\text {factori }}\right) / \Delta D O C_{\text {all }}$. Simulation attribution analysis has been widely used and details can be found in recent publications [Tao et al., 2014; Tian et al., 2012; Xu et al., 2012].

\section{Results}

\subsection{Environmental Changes Across the Mississippi River Basin}

The Mississippi River basin has experienced substantial changes and variability in climate (i.e., temperature and precipitation), atmospheric $\mathrm{CO}_{2}$ concentration, nitrogen $\left(\mathrm{NO}_{x}\right.$ and $\mathrm{NH}_{3}$ ) deposition, and land use and land cover since 1901 (Figures 3 and 4). We found large year-to-year variations in precipitation and mean air temperature, although no significant long-term trends were evident in the past 110 years (Figure 3a). There were three severe droughts (large increase in temperature and decrease in precipitation) that occurred in the 1930s, 1950s, and 2000s and two exceptionally wet periods (large increase in precipitation and small change in temperature) in the 1940s and 1970s. Atmospheric $\mathrm{CO}_{2}$ concentration increased from $296 \mathrm{ppm}$ to 385 ppm and nitrogen deposition $\left(\mathrm{g} \mathrm{N} \mathrm{m}^{-2}\right.$ ) nearly doubled (Figure 3b). Land use and land cover also changed substantially. Cropland expanded at the expense of natural ecosystems across the entire basin. While grasslands were continually lost during the interval, cropland abandonment and reforestation occurred since 
(a)

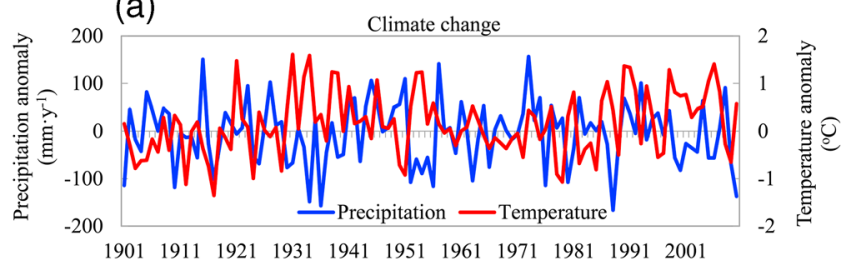

(b)

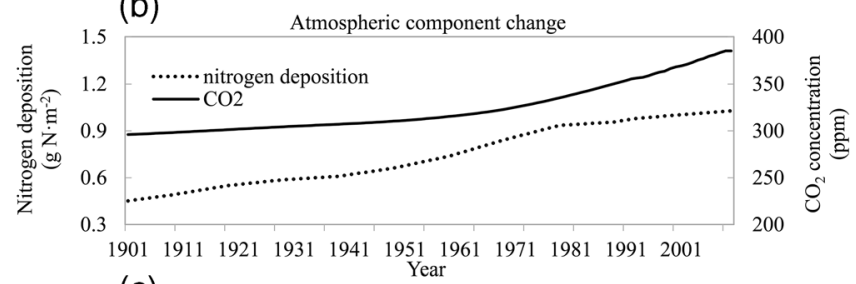

(c)

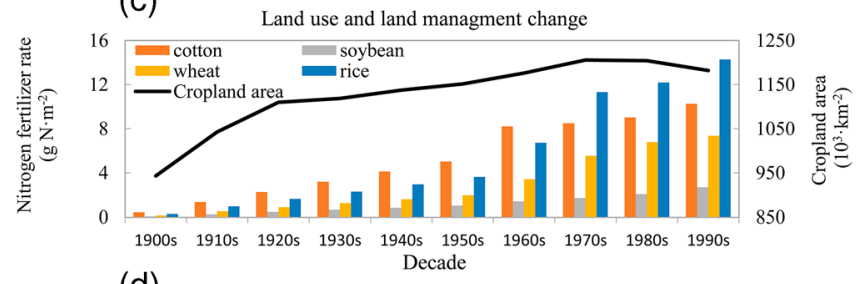
(d)

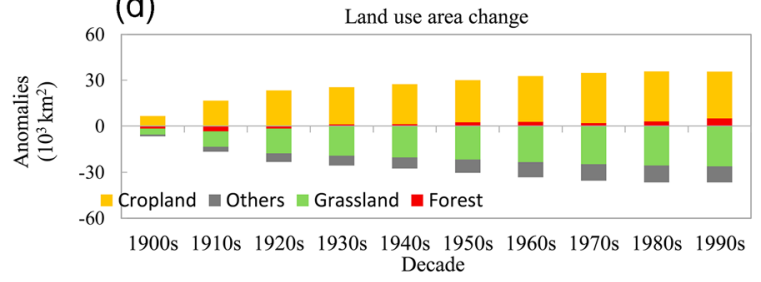

Figure 3. Temporal changes in multiple environmental factors during 19012010. (a) Climate (average temperature and precipitation); (b) atmospheric components ( $\mathrm{CO}_{2}$ and nitrogen deposition); (c) land use and land management (cropland area and nitrogen fertilizer rate); (d) decadal mean of changes in cropland, forest, grassland, and other types relative to the initial year (1900) across the Mississippi River basin over the 20th century. the 1930s in the upper and lower Ohio River basins (Figures 3c, 3d, and 4) [Liu et al., 2013]. Cropland was managed very intensely, especially through the increased application of nitrogen fertilizers (Figure 3c).

\subsection{Long-Term and Recent Trends} in DOC Concentration and Flux

Simulation results show significant, long-term increases in both DOC concentration and export during 19012010 (Mann-Kendall trend test, $p<0.001)$. Mean annual export of DOC averaged over decadal intervals increased by over $40 \%$ from $1.8 \pm 0.3$ $\mathrm{TgC} \mathrm{yr}^{-1}$ in the 1900 s to $2.6 \pm 0.4 \mathrm{Tg}$

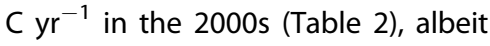
with large interannual variations (Figure 5). Furthermore, DOC concentrations in the estuary increased by approximately $70 \%$ over the study period, with small interannual variations. Seasonality analysis for the entire period shows that $75 \%$ of total annual export occurred over just half the year, in winter $(37 \%$ of total export) and spring (37\% of total export) (Table 2 and Figure S3). USGS observations derived from the WRTDS estimation also showed increasing trends in annual DOC concentration and DOC export (DOC concentration multiplied by water discharge) for the period 1931-

2010) (Mann-Kendall trend test, $p<0.001$ ) (Figure S1). The modeled temporal patterns were consistent with observations (Figures 2 and S2). In recent decades since 1981, both model simulations and USGS WRTDS estimations show large variations in annual water discharge and DOC export with slightly decreasing trends, while annual DOC concentration remained relatively stable.

\subsection{Spatial Patterns of DOC Fluxes During 1901-2010}

Large spatial variations in riverine DOC flux were found between the various subbasins of the Mississippi River system (Figures 6a and 6b). In general, DOC export was relatively high in the eastern area (Ohio and Mississippi Rivers) and low in the western part of the basin (Arkansas and Missouri Rivers). Substantial temporal increases in DOC export were attributable to the eastern basins, specifically the upper Mississippi River basin, upper and lower Ohio River basins, and eastern parts of the Arkansas and Ouachita River basins. We further examined the variations of riverine DOC export in specific years over the 20th century that coincided with severe droughts and heavy flooding events (Figure 6). We found dramatic differences in DOC export between wet and dry intervals that differed among regions. In drought years (Figures $6 c, 6 e$, and $6 \mathrm{~g}$ ), riverine DOC export was quite low across the whole basin (approximately 12\% lower relative to the 110 year average). In flood years (Figures $6 \mathrm{~d}, 6 \mathrm{f}$, and $6 \mathrm{~h}$ ), relatively high riverine DOC export was found, but in different flooded areas (approximately 54\% higher compared to the 110 year average). For example, high riverine DOC export was found in the central Mississippi River basin in 1993 (Figure 6h), and in the northeastern Mississippi River basin in 1973 (Figure 6f). 

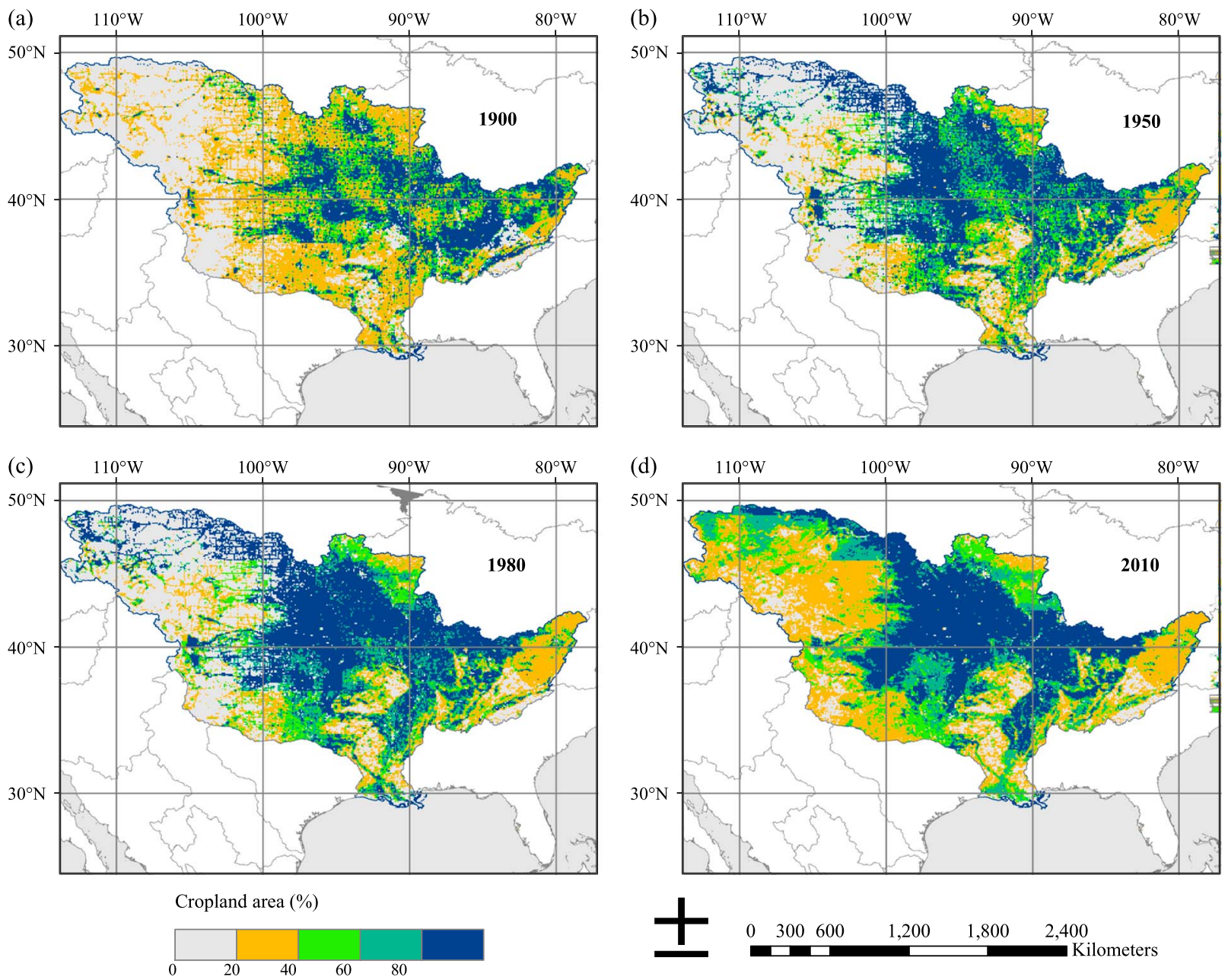

Figure 4. Fractional area of each 5 min grid cell used for cropland (\%) in (a) 1900, (b) 1950, (c) 1980, and (d) 2000.

\subsection{DOC Export Responses to Multiple Environmental Factors}

Numerical simulations presented here provide evidence that human activities were the dominant factor contributing to the long-term increase in riverine DOC export. Land use management was responsible for $43 \%$ of the long-term increase, while land conversion contributed another $33 \%$ (76\% collectively). $\mathrm{CO}_{2}, \mathrm{Ndep}$, and Climate increased DOC export by $25 \%, 18 \%$, and $9 \%$, respectively. The interactive effect of all the above

Table 2. Decadal Mean of Annual and Seasonal DOC Export from the Mississippi River Basin and Magnitude of Changes in Export Relative to Decadal Mean Export in the 1900s (1900-1910) ${ }^{\mathrm{a}}$

\begin{tabular}{lccccc} 
& Winter & Spring & Summer & Fall & Annual \\
\hline & \multicolumn{5}{c}{ Decadal Mean DOC Export $\left(\operatorname{TgC~yr}^{-1}\right)$} \\
$1900 \mathrm{~s}$ & $0.66 \pm 0.14$ & $0.66 \pm 0.14$ & $0.30 \pm 0.09$ & $0.19 \pm 0.05$ & $1.81 \pm 0.32$ \\
$1950 \mathrm{~s}$ & $0.69 \pm 0.20$ & $0.82 \pm 0.16$ & $0.31 \pm 0.09$ & $0.19 \pm 0.08$ & $2.01 \pm 0.43$ \\
$1990 \mathrm{~s}$ & $1.03 \pm 0.30$ & $0.99 \pm 0.28$ & $0.45 \pm 0.10$ & $0.28 \pm 0.11$ & $2.75 \pm 0.67$ \\
$2000 \mathrm{~s}$ & $0.98 \pm 0.24$ & $0.94 \pm 0.20$ & $0.41 \pm 0.12$ & $0.29 \pm 0.10$ & $2.62 \pm 0.45$ \\
110 Year Average & $0.83 \pm 0.16$ & $0.84 \pm 0.12$ & $0.34 \pm 0.06$ & $0.21 \pm 0.05$ & $2.23 \pm 0.38$ \\
& Change in Export Relative to the $1900 \mathrm{~s}$ Decadal Mean & \\
$1950 \mathrm{~s}-1900 \mathrm{~s}$ & $5 \%$ & $22 \%$ & $3 \%$ & $-4 \%$ & $10.5 \%$ \\
$1990 \mathrm{~s}-1900 \mathrm{~s}$ & $58 \%$ & $47 \%$ & $47 \%$ & $42 \%$ & $51.1 \%$ \\
$2000 \mathrm{~s}-1900 \mathrm{~s}$ & $50 \%$ & $41 \%$ & $33 \%$ & $44 \%$ & $43.8 \%$ \\
\hline
\end{tabular}

\footnotetext{
${ }^{a}$ The \pm values reflect the average variation in DLEM simulations during the decade for each season and year due to
} variations in streamflow and other forcing data. 


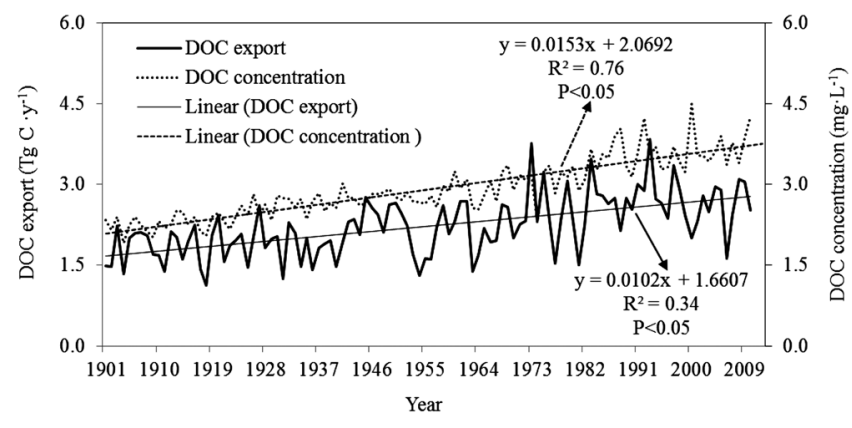

Figure 5. Simulated annual changes in dissolved organic carbon (DOC) export $\left(\mathrm{TgC}_{\mathrm{yr}}{ }^{-1}\right)$ and DOC concentration $\left(\mathrm{mg} \mathrm{L}^{-1}\right)$ during 1901-2010. study period. LC also contributed to increasing DOC export in the 1950s; however, its contribution to DOC export leveled off over the past 40 years.

\section{Discussion}

The increase in riverine DOC export from land to ocean can be caused by increased river discharge, increases in the concentrations of DOC, or both. A variety of studies have been conducted to distinguish the roles of natural and anthropogenic factors contributing to DOC flux [Christ and David, 1996; Harley et al., 2006; Monteith et al., 2007; Oh et al., 2013; Pandey and Pandey, 2013; Tian et al., 2013], in the context of rapidly changing environmental conditions that influence global water and biogeochemical cycles. Yet debates still exist regarding the roles of these factors in increasing or decreasing DOC export. A recent synthesis concluded that anthropogenic perturbations involving land use change, soil erosion, fertilizer use, and municipal sewage water inputs were major factors in stimulating DOC export through enhancement of both DOC source inputs and river discharge [Regnier et al., 2013]. It is often difficult to separate the influence of natural carbon dynamics from human perturbations on carbon export. Our simulation "experiments" provide a means to separate the influences of these factors.

Our results shed light on the contribution of various factors affecting DOC export as well as offering insights into the mechanisms contributing to system responses. Human activities including LC and LMPs (fertilization, irrigation, tillage, etc.) accounted for the largest increase, more than 76\%, in DOC export. Based on our LCLUC simulation experiments, we conclude that the combined effects of land cover change and management practices have led to a large increase in DOC sources and consequently DOC export, even though river discharge has decreased slightly. Based on single-factor simulations (LC and LMPs), we further separated the effects of land cover change from management practices. On average, LC alone contributed 33\% to the total increase in DOC export, peaking in the 1950s as rapid crop expansion and reforestation occurred in the Mississippi River basin [Foley et al., 2004; Turner and Rabalais, 2003]. One explanation is that land conversion from forests (or grassland) to cropland reduces water loss to the atmosphere through evapotranspiration while increasing runoff, which in turn leads to increased DOC export [Dunn, 1996]. Alternatively, a large amount of DOC may be released through cultivation-intensified degradation of the organic matter during the initial stages of forest clearing for agriculture [Bauer and Bianchi, 2011; Delprat et al., 1997]. During later stages, as the original organic matter is stabilized, DOC concentrations decrease with duration of cultivation. At the same time, reforestation in the upper and lower Ohio basins is believed to have contributed to an increase in DOC export due to higher DOC leaching in forest land compared to other systems [Delprat et al., 1997; Pandey and Pandey, 2013]. Since the 1950s, LC change (changed crop expansion pace and reforestation rate) affected both water discharge and DOC sources [Foley et al., 2004] but had a relatively small impact on DOC export. LMPs, particularly those associated with fertilizer use (Figure 2c), played a dominant role in enhancing DOC export through stimulation of crop net primary productivity, organic matter decomposition, and DOC production and leaching. This finding is consistent with Liu and Greaver's conclusion that nitrogen addition generally results in an increase in the carbon content of the organic layers in soil and DOC concentration, which is associated with an increase in carbon leaching [Liu and Greaver, 2010].

We also examined the relative contributions of environmental factors including Climate, $\mathrm{CO}_{2}$, and Ndep to $\mathrm{DOC}$ export. Our findings indicate a positive effect of elevated atmospheric $\mathrm{CO}_{2}$ concentration on DOC 
(a)

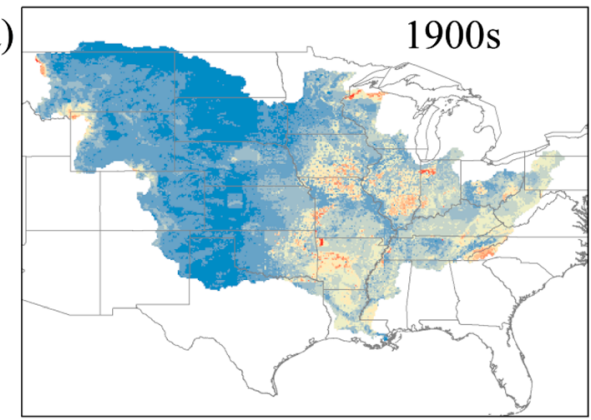

(c)

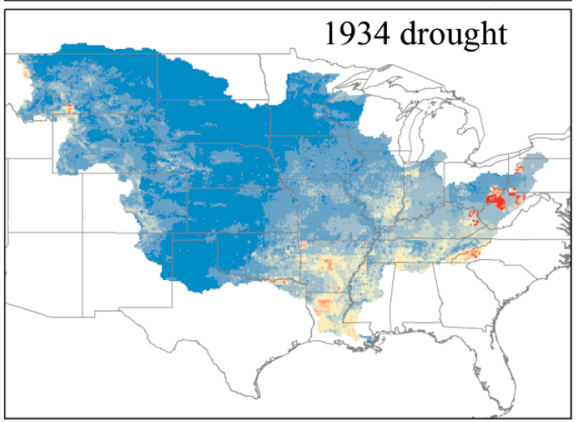

(e)

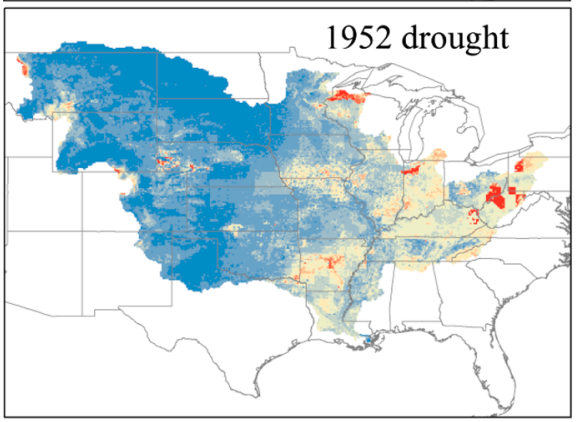

(g)

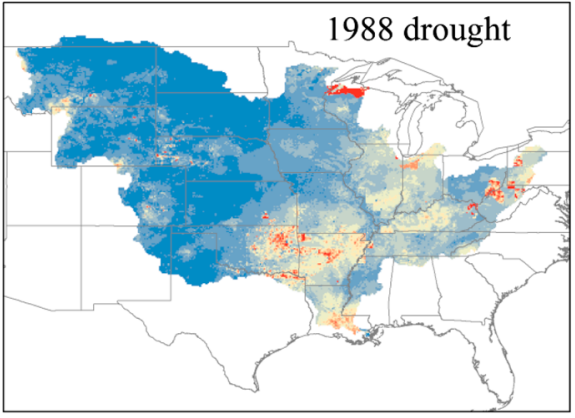

DOC leaching (g C m-2)

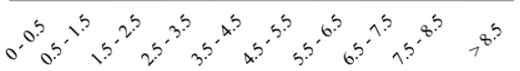

(b)

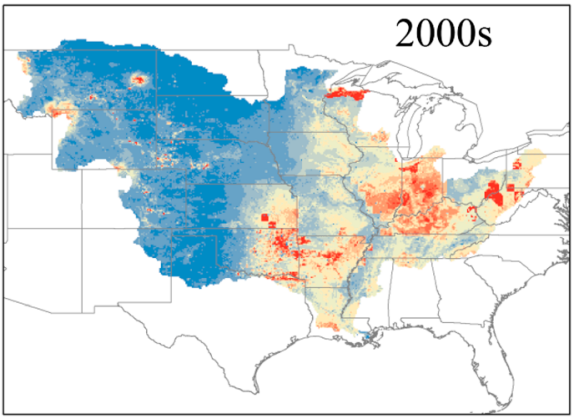

(d)

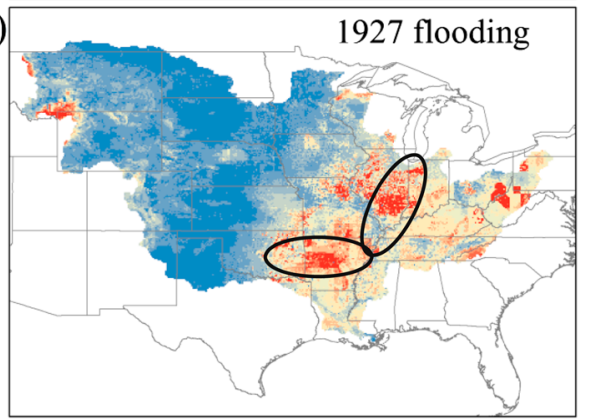

(f)

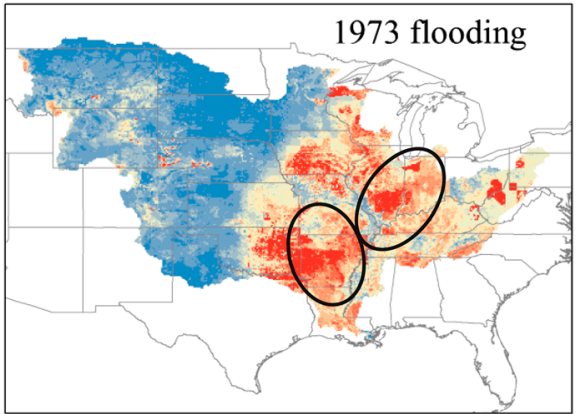

(h)

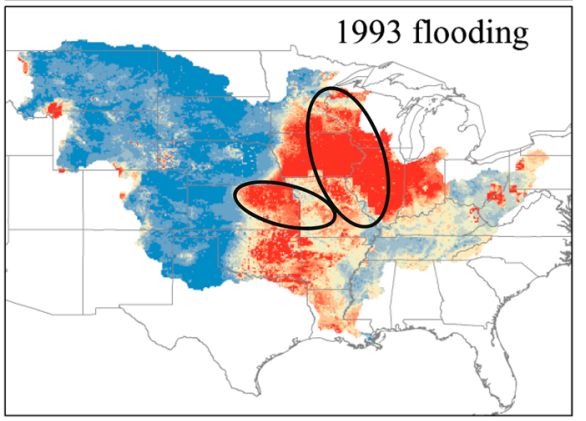

$\bigwedge^{N}$

$\begin{array}{lllll}03.757 .5 & 15 & 22.5 & 30 & 37.5\end{array}$

Kilometers

Figure 6. Spatial distributions of dissolved organic carbon (DOC) export $\left(\mathrm{Tg} \mathrm{Cyr}^{-1}\right)$ (a) in the 1900s and (b) in the 2000s, and in severe drought years (c) 1934, (e) 1952, and (g) 1988, and flooding years (d) 1927, (f) 1973, and (h) 1993. Black circles show flooding regions.

export, as a result of $\mathrm{CO}_{2}$-enhanced net primary productivity and subsequent soil organic carbon decomposition [Freeman et al., 2004]. Similar to nitrogen fertilizer effects, Ndep also significantly enhanced DOC sources by influencing productivity, litter chemistry, carbon allocation, and associated microbial decomposition dynamics. Those conclusions are supported by previous studies [Findlay, 2005; LeBauer and Treseder, 2008; Monteith et al., 2007; Sinsabaugh et al., 2004]. 

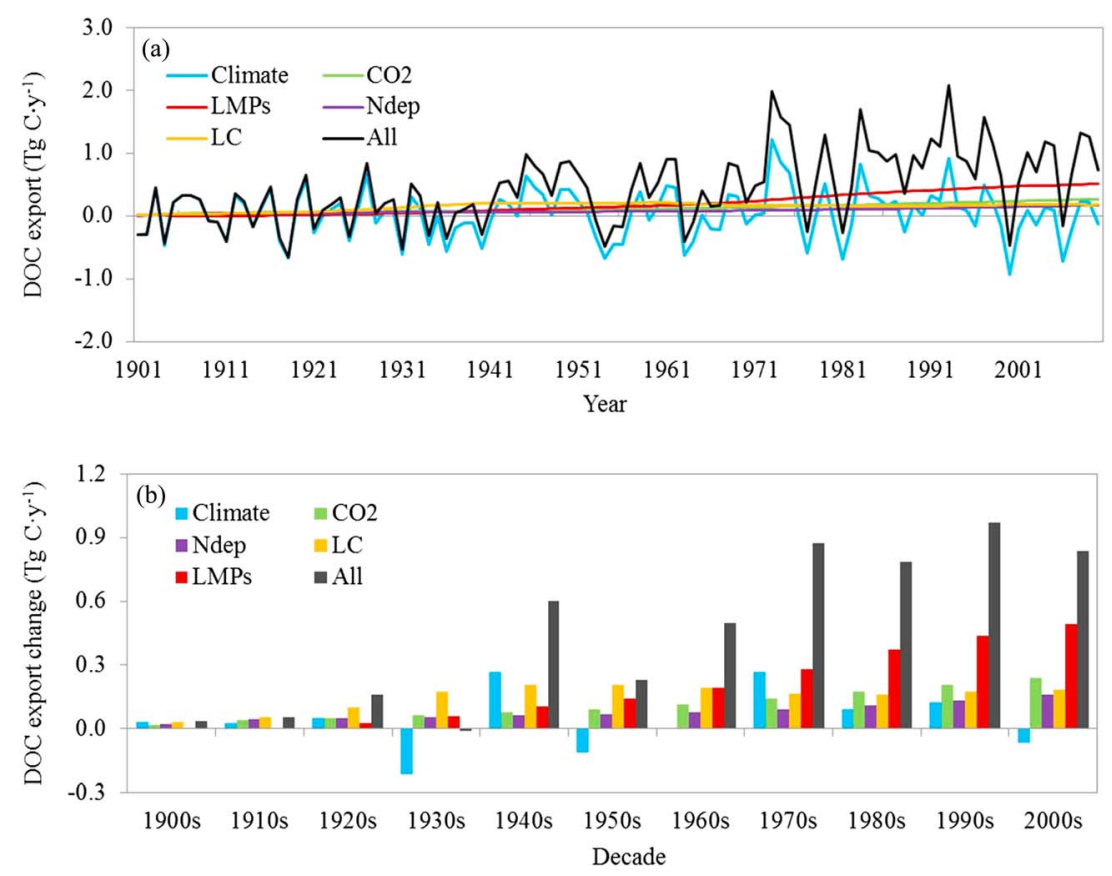

Figure 7. Changes in (a) annual DOC export and (b) decadal mean DOC export induced by multiple environmental factors including climate change (Climate), atmospheric $\mathrm{CO}_{2}$, nitrogen deposition (Ndep), land cover change (LC), and land management (LMPs) during 1901-2010.

DOC export in our study showed substantial interannual variations in response to climate variability. DOC export increased during extreme flooding, in agreement with other studies about climate extremes (i.e., storm events) [Hood et al., 2006; Inamdar and Mitchell, 2006; Jeong et al., 2012]. We further isolated the effects of long-term changes in precipitation (PRECIP) from temperature ( $T$ ) on DOC export using singlefactor experiments. Across the entire basin, $T$ was associated with small changes in DOC export while PRECIP accounted for the majority (over 95\%) of annual DOC export variability related to climate change. Relative to other factors' contributions to DOC export, the effects of $T$ and PRECIP were less, but a regional analysis revealed larger effects of $T$ and PRECIP in the relatively moist eastern part of the basin. We conclude that climate effects will have a greater impact on riverine DOC yields in cooler and wetter regions [Tian et al., 2013].

Our study not only investigated the magnitude and tempo-spatial patterns of riverine DOC export but also attributed the roles of natural and anthropogenic factors to increased DOC export using a spatially explicit coupled hydrologic/biogeochemical land simulation model. However, several other potentially important factors were excluded in this study and warrant further evaluation, including river engineering (e.g., dams), agronomic practices (e.g., manure application), and other DOC sources such as autochthonous DOC production from riverine algae [Bianchi et al., 2007; Bianchi et al., 2004]. Further improvement in model representation of additional biogeochemical processes in river systems and the spatial data sets of dams and agronomic practices are needed to reduce uncertainties.

We also conducted sensitivity analyses of key parameters related to DOC fluxes by testing the changes in simulated DOC fluxes in response to a $10 \%$ increase and decrease of each parameter. For example, we found that DOC export would be enhanced by approximately $2.6 \%$ with a $10 \%$ decrease in the soil DOC desorption coefficient, while a $10 \%$ increase in this parameter has a relatively small effect $(0.4 \%$ reduction in DOC export). Parameters are a major source of uncertainty in our estimation of total DOC export. Therefore, future information obtained from site-level observations both on land and in coastal areas, and regional monitoring and observations from remote sensing, can be used for further model development, parameterization, and evaluation. In addition, higher temporal and spatial resolution regional input data (e.g., nitrogen deportation and land management practices including manure and nitrogen fertilizer use) to support ecosystem models will also improve the accuracy of regional assessments of DOC export. 


\section{Conclusions}

Our Dynamic Land Ecosystem Model (DLEM) simulated the spatial and temporal patterns of DOC fluxes from the Mississippi River basin for the past 110 years. We found a significant trend of increasing DOC export resulting from multiple environmental changes and variations including climate change (temperature and precipitation), rising atmospheric $\mathrm{CO}_{2}$ concentration, nitrogen deposition, land use change, and land management practices. This study provides the first characterization of DOC export dynamics from the entire basin over the past century and offers a novel attempt to quantify the relative importance of natural and anthropogenic forces to changes in DOC export through linking terrestrial and riverine biogeochemical processes. Development and improvement of the representation of additional biogeochemical processes in the linked terrestrial and riverine modeling systems and finer temporal and spatial resolution of data sets can further advance the performance of this approach for application at whole and subbasin scales.

\section{Acknowledgments}

This study has been supported by NASA Interdisciplinary Science Programs (NNX10AU06G) and Carbon System Monitoring Program (NX14AO73G and NNX12AP84G). Partial support was also provided by NSF OCE-1238212 (CSH), NSF OCE-1237140 (CSH \& WJC). CSH is an affiliated member of the UGA RBC, CICR and UGAMI (Contr\#1053). Data supporting Tables 1 and 2 and Figures 2-7 in the article and Table S1 and Figures S1-S3 in the supporting information are available as in section 2. We thank the U.S. Geological Survey (USGS: http://toxics.usgs.gov/hypoxia/ mississippi/real_time.html) for providing open water quality data to support this study; we thank the U.S. Army Corp (http://rivergages.mvr.usace.army.mil/ WaterControl/stationinfo2.cfm? sid $=01100 \mathrm{Q}$ ) for providing river discharge data. We also thank Jennifer Warrillow for proofreading this manuscript.

\section{References}

Aitkenhead, J. A., and W. H. McDowell (2000), Soil C:N ratio as a predictor of annual riverine DOC flux at local and global scales, Global Biogeochem. Cycles, 14, 127-138, doi:10.1029/1999GB900083.

Bauer, J. E., and T. S. Bianchi (2011), Dissolved organic carbon cycling and transformation, in Treatise on Estuarine and Coastal Science, Biogeochemistry, vol. 5, pp. 7-67, Academic, Press, Waltham.

Bengtson, P., and G. Bengtsson (2007), Rapid turnover of DOC in temperate forests accounts for increased $\mathrm{CO}_{2}$ production at elevated temperatures, Ecol. Lett., 10(9), 783-790.

Benner, R., and S. Opsahl (2001), Molecular indicators of the sources and transformations of dissolved organic matter in the Mississippi River plume, Org. Geochem., 32(4), 597-611.

Bianchi, T. S., T. Filley, K. Dria, and P. G. Hatcher (2004), Temporal variability in sources of dissolved organic carbon in the lower Mississippi River, Geochim. Cosmochim. Acta, 68(5), 959-967.

Bianchi, T. S., J. J. Galler, and M. A. Allison (2007), Hydrodynamic sorting and transport of terrestrially derived organic carbon in sediments of the Mississippi and Atchafalaya Rivers, Estuarine Coastal Shelf Sci., 73(1-2), 211-222.

Butman, D., and P. A. Raymond (2011), Significant efflux of carbon dioxide from streams and rivers in the United States, Nat. Geosci., 4(12), 839-842.

Butman, D., S. Stackpoole, E. Stets, C. P. McDonald, D. W. Clow, and R. G. Striegl (2016), Aquatic carbon cycling in the conterminous United States and implications for terrestrial carbon accounting, Proc. Natl. Acad. Sci. U. S. A., 113(1), 58-63, doi:10.1073/pnas.1512651112.

Canuel, E. A., S. S. Cammer, H. A. McIntosh, and C. R. Pondell (2012), Climate change impacts on the organic carbon cycle at the land-ocean interface, Annu. Rev. Earth Planet. Sci., 40, 685-711.

Chantigny, M. H. (2003), Dissolved and water-extractable organic matter in soils: A review on the influence of land use and management practices, Geoderma, 113(3-4), 357-380.

Chen, G. S., H. Q. Tian, C. Zhang, M. L. Liu, W. Ren, W. Q. Zhu, A. H. Chappelka, S. A. Prior, and G. B. Lockaby (2012), Drought in the Southern United States over the 20th century: Variability and its impacts on terrestrial ecosystem productivity and carbon storage, Clim. Change, 114(2), 379-397.

Chen, H., H. Q. Tian, M. L. Liu, J. Melillo, S. F. Pan, and C. Zhang (2006), Effect of land-cover change on terrestrial carbon dynamics in the southern United States, J. Environ. Qual., 35(4), 1533-1547.

Christ, M. J., and M. B. David (1996), Temperature and moisture effects on the production of dissolved organic carbon in a Spodosol, Soil Biol. Biochem., 28(9), 1191-1199.

Coe, M. T. (2000), Modeling terrestrial hydrological systems at the continental scale: Testing the accuracy of an atmospheric GCM, J. Clim. 13(4), 686-704.

Cole, J. J., et al. (2007), Plumbing the global carbon cycle: Integrating inland waters into the terrestrial carbon budget, Ecosystems, 10(1), 171-184

Dai, M. H., Z. Q. Yin, F. F. Meng, Q. Liu, and W. J. Cai (2012), Spatial distribution of riverine DOC inputs to the ocean: An updated global synthesis, Curr. Opin. Environ. Sustain., 4(2), 170-178.

Delprat, L., P. Chassin, M. Lineres, and C. Jambert (1997), Characterization of dissolved organic carbon in cleared forest soils converted to maize cultivation, Eur. J. Agron., 7(1-3), 201-210.

Dhillon, G. S., and S. Inamdar (2013), Extreme storms and changes in particulate and dissolved organic carbon in runoff: Entering uncharted waters?, Geophys. Res. Lett., 40, 1322-1327, doi:10.1002/grl.50306.

Dunn, D. D. (1996), Trends in nutrient inflows to the Gulf of Mexico from streams draining the conterminous United States, Rep.1972-93, U.S. Geol. Surv., Austin, Texas.

Findlay, S. E. G. (2005), Increased carbon transport in the Hudson River: Unexpected consequence of nitrogen deposition?, Front. Ecol. Environ., 3(3), 133-137.

Foley, J. A., C. J. Kucharik, T. E. Twine, M. T. Coe, and S. D. Donner (2004), Land use, land cover, and climate change across the Mississippi basin: Impacts on selected land and water resources, in Ecosystems and Land Use Change, pp. 249-261, AGU, Washington, D. C.

Freeman, C., N. Fenner, N. J. Ostle, H. Kang, D. J. Dowrick, B. Reynolds, M. A. Lock, D. Sleep, S. Hughes, and J. Hudson (2004), Export of dissolved organic carbon from peatlands under elevated carbon dioxide levels, Nature, 430(6996), 195-198.

Harley, C. D. G., A. R. Hughes, K. M. Hultgren, B. G. Miner, C. J. B. Sorte, C. S. Thornber, L. F. Rodriguez, L. Tomanek, and S. L. Williams (2006), The impacts of climate change in coastal marine systems (vol 9, pg 228, 2006), Ecol. Lett., 9(4), 500.

Harrison, J. A., N. Caraco, and S. P. Seitzinger (2005), Global patterns and sources of dissolved organic matter export to the coastal zone: Results from a spatially explicit, global model, Global Biogeochem. Cycles, 19, GB4S04, doi:10.1029/2005GB002480.

Hedges, J. I. (1992), Global biogeochemical cycles_Progress and problems, Mar. Chem., 39(1-3), 67-93.

Hirsch, R. M. (2014), Large biases in regression-based constituent flux estimates: Causes and diagnostic tools, J. Am. Water Resour. Assoc., 50(6), 1401-1424.

Hood, E., M. N. Gooseff, and S. L. Johnson (2006), Changes in the character of stream water dissolved organic carbon during flushing in three small watersheds, Oregon, J. Geophys. Res., 111, G01007, doi:10.1029/2005JG000082. 
Inamdar, S. P., and M. J. Mitchell (2006), Hydrologic and topographic controls on storm-event exports of dissolved organic carbon (DOC) and nitrate across catchment scales, Water Resour. Res., 42, W03421, doi:10.1029/2005WR004212.

Jeong, J. J., S. Bartsch, J. H. Fleckenstein, E. Matzner, J. D. Tenhunen, S. D. Lee, S. K. Park, and J. H. Park (2012), Differential storm responses of dissolved and particulate organic carbon in a mountainous headwater stream, investigated by high-frequency, in situ optical measurements, J. Geophys. Res., 117, G03013, doi:10.1029/2012JG001999.

LeBauer, D. S., and K. K. Treseder (2008), Nitrogen limitation of net primary productivity in terrestrial ecosystems is globally distributed, Ecology, 89(2), 371-379.

Liu, J. X., D. T. Price, and J. A. Chen (2005), Nitrogen controls on ecosystem carbon sequestration: A model implementation and application to Saskatchewan, Canada, Ecol. Modell., 186(2), 178-195.

Liu, L. L., and T. L. Greaver (2010), A global perspective on belowground carbon dynamics under nitrogen enrichment, Ecol. Lett., 13(7), 819-828.

Liu, M. L., H. Q. Tian, Q. C. Yang, J. Yang, X. Song, S. E. Lohrenz, and W. J. Cai (2013), Long-term trends in evapotranspiration and runoff over the drainage basins of the Gulf of Mexico during 1901-2008, Water Resour. Res., 49, 1988-2012, doi:10.1002/wrcr.20180.

Lohrenz, S. E., W. J. Cai, S. Chakraborty, K. Gundersen, and M. C. Murrell (2014), Nutrient and carbon dynamics in a large river-dominated coastal ecosystem: The Mississippi-Atchafalaya River system, in Biogeochemical Dynamics at Major River-Coastal Interfaces: Linkages with Global Change, pp. 448-472, Cambridge Univ. Press, Cambridge, U. K.

Ludwig, W., J. L. Probst, and S. Kempe (1996), Predicting the oceanic input of organic carbon by continental erosion, Global Biogeochem. Cycles, 10, 23-41, doi:10.1029/95GB02925.

Mackenzie, F. T., L. M. Ver, and A. Lerman (2000), Coastal-zone biogeochemical dynamics under global warming (vol 42, pg 193, 2000), Int. Geol. Rev., 42(12), 1148-1149.

Meybeck, M. (1993), Riverine transport of atmospheric carbon-Sources, global typology and budget, Water Air Soil Pollut., 70(1-4), 443-463.

Monteith, D. T., et al. (2007), Dissolved organic carbon trends resulting from changes in atmospheric deposition chemistry, Nature, 450(7169), 537-539.

Oh, N. H., B. A. Pellerin, P. A. M. Bachand, P. J. Hernes, S. M. Bachand, N. Ohara, M. L. Kavvas, B. A. Bergamaschi, and W. R. Horwath (2013), The role of irrigation runoff and winter rainfall on dissolved organic carbon loads in an agricultural watershed, Agric. Ecosyst. Environ., 179, 1-10.

Pan, S. F., H. Q. Tian, S. R. S. Dangal, Q. C. Yang, J. Yang, C. Q. Lu, B. Tao, W. Ren, and Z. Y. Ouyang (2015), Responses of global terrestrial evapotranspiration to climate change and increasing atmospheric $\mathrm{CO}_{2}$ in the 21 st century, Earths Future, 3(1), 15-35.

Pandey, U., and J. Pandey (2013), Impact of DOC trends resulting from changing climatic extremes and atmospheric deposition chemistry on periphyton community of a freshwater tropical lake of India, Biogeochemistry, 112(1-3), 537-553.

Parton, W. J., et al. (1993), Observations and modeling of biomass and soil organic-matter dynamics for the grassland biome worldwide, Global Biogeochem. Cycles, 7, 785-809, doi:10.1029/93GB02042.

Petersen, B. M., J. Berntsen, S. Hansen, and L. S. Jensen (2005), CN-SIM-A model for the turnover of soil organic matter. I. Long-term carbon and radiocarbon development, Soil Biol. Biochem., 37(2), 359-374.

Regnier, P., et al. (2013), Anthropogenic perturbation of the carbon fluxes from land to ocean, Nat. Geosci., 6(8), $597-607$.

Ren, W., H. Q. Tian, B. Tao, J. Yang, S. F. Pan, W. J. Cai, S. E. Lohrenz, R. Y. He, and C. S. Hopkinson (2015), Large increase in dissolved inorganic carbon flux from the Mississippi River to Gulf of Mexico due to climatic and anthropogenic changes over the 21st century, J. Geophys. Res. Biogeosci., 120, 724-736, doi:10.1002/2014JG002761.

Schlesinger, W. H., and J. M. Melack (1981), Transport of organic-carbon in the worlds rivers, Tellus, 33(2), 172-187.

Shen, Y., C. G. Fichot, and R. Benner (2012), Floodplain influence on dissolved organic matter composition and export from the MississippiAtchafalaya River system to the Gulf of Mexico, Limnol. Oceanogr., 57(4), 1149-1160.

Sinsabaugh, R. L., D. R. Zak, M. Gallo, C. Lauber, and R. Amonette (2004), Nitrogen deposition and dissolved organic carbon production in northern temperate forests, Soil Biol. Biochem., 36(9), 1509-1515.

Smith, S. V., and J. T. Hollibaugh (1993), Coastal metabolism and the oceanic organic-carbon balance, Rev. Geophys., 31, 75-89, doi:10.1029/ 92RG02584.

Smith, S. V., R. O. Sleezer, W. H. Renwick, and R. Buddemeier (2005), Fates of eroded soil organic carbon: Mississippi basin case study, Ecol. Appl., 15(6), 1929-1940.

Stets, E. G., and R. G. Striegl (2012), Carbon export by rivers draining the conterminous United States, Inland Waters, 2(4), $177-184$.

Tao, B., H. Q. Tian, W. Ren, J. Yang, Q. C. Yang, R. Y. He, W. J. Cai, and S. Lohrenz (2014), Increasing Mississippi River discharge throughout the 21 st century influenced by changes in climate, land use, and atmospheric $\mathrm{CO}_{2}$, Geophys. Res. Lett., 41, 4978-4986, doi:10.1002/ 2014GL060361.

Tian, H. Q., X. Xu, M. Liu, W. Ren, C. Zhang, G. Chen, and C. Lu (2010), Spatial and temporal patterns of $\mathrm{CH}_{4}$ and $\mathrm{N}_{2} \mathrm{O}$ fluxes in terrestrial ecosystems of North America during 1979-2008: Application of a global biogeochemistry model, Biogeosciences, 7(9), $2673-2694$.

Tian, H. Q., et al. (2012), Century-scale responses of ecosystem carbon storage and flux to multiple environmental changes in the Southern United States, Ecosystems, 15(4), 674-694.

Tian, H. Q., et al. (2015), Climate extremes dominating seasonal and interannual variations in carbon export from the Mississippi River basin Global Biogeochem. Cycles, 29, 1333-1347, doi:10.1002/2014GB005068.

Tian, Y. Q., Q. Yu, A. D. Feig, C. J. Ye, and A. Blunden (2013), Effects of climate and land-surface processes on terrestrial dissolved organic carbon export to major US coastal rivers, Ecol. Eng., 54, 192-201.

Trefry, J.H., S. Metz, T. Nelsen, R. Trocine, and B. Eadie (1994), Transport of particulate organic carbon by the Mississippi River and its fate in the Gulf of Mexico, Estuaries, 17, 839-849, doi:10.2307/1352752.

Turner, R. E., and N. N. Rabalais (2003), Linking landscape and water quality in the Mississippi River basin for 200 years, BioScience, 53(6), 563-572.

Xu, X. F., H. Q. Tian, G. S. Chen, M. L. Liu, W. Ren, C. Q. Lu, and C. Zhang (2012), Multifactor controls on terrestrial $\mathrm{N}_{2} \mathrm{O}$ flux over North America from 1979 through 2010, Biogeosciences, 9(4), 1351-1366.

Yang, Q., et al. (2015), Spatiotemporal patterns of evapotranspiration along the North American east coast as influenced by multiple environmental changes, Ecohydrology, 8(4), 714-725, doi:10.1002/eco.1538.

Zhang, C., et al. (2012), Impacts of urbanization on carbon balance in terrestrial ecosystems of the Southern United States, Environ. Pollut., 164, 89-101.

Zhang, L. J., L. Wang, W. J. Cai, D. M. Liu, and Z. G. Yu (2013), Impact of human activities on organic carbon transport in the Yellow River, Biogeosciences, 10(4), 2513-2524. 